FAKTOR RISIKO MATERNAL BAYI BERAT LAHIR RENDAH (BBLR): STUDI SYSTEMATIC REVIEW

\title{
MATERNAL RISK FACTORS OF LOW BIRTH WEIGHT (LBW): SYSTEMATIC REVIEW
}

\author{
Jianti Fina Lestari ${ }^{1}$, Risa Etika ${ }^{2}$, Pudji Lestari ${ }^{3}$
}

1. Program Studi Kebidanan, Fakultas Kedokteran Universitas Airlangga, Surabaya

2. Departemen Ilmu Kesehatan Anak, Fakultas Kedokteran Universitas Airlangga, Surabaya

3. Departemen Ilmu Kesehatan Masyarakat-Kedokteran Pencegahan, Fakultas

Kedokteran Universitas Airlangga, Surabaya

Alamat korespondensi:

Jalan Piranha Atas RT 06 RW 01 Malang, Indonesia

Email : finnalestari@gmail.com

\begin{abstract}
Abstrak
Latar Belakang : Bayi Berat Lahir Rendah (BBLR) menyumbang $60-80 \%$ dari seluruh kematian neonatal di dunia. Tidak hanya menjadi prediktor utama bagi mortalitas dan morbiditas pada neonatus, individu dengan riwayat BBLR memiliki risiko lebih besar mengalami berbagai penyakit seperti hipertensi, penyakit jantung, dan diabetes di kemudian hari. Studi systematic review ini bertujuan untuk mengidentifikasi faktor risiko maternal yang berkotribusi pada kejadian BBLR. Metode: Artikel yang diterbitkan antara tahun 2015 - 2020 dalam database Science Direct, Scopus, dan Cochrane library ditinjau secara sistematik. Sebelas artikel yang memenuhi kriteria inklusi dan eksklusi, diikut sertakan sebagai sample untuk ditinjau lebih lanjut. Hasil-hasil mengenai faktor risiko maternal pada kejadian BBLR disintesis secara sistematik. Hasil: Dari hasil pencarian didapatkan 818 artikel, setelah dilakukan proses screening di dapatkan hasil akhir 11 artikel. Faktor risiko yang secara signifikan berkaitan dengan kejadian BBLR pada artikel, dikelompokan dalam subtema, antara lain : usia ibu ( $<20$ tahun, dan setiap peningkatan usia), paritas (primipara dan grandemultipara), lingkar lengan ibu rendah, kadar hemoglobin kurang dari $11 \mathrm{gr} / \mathrm{dl}$, usia kehamilan dibawah 37 minggu, komplikasi selama hamil. Kesimpulan: Usia ibu, paritas, lingkar lengan, kadar hemoglobin, usia kehamilan, dan komplikasi selama hamil, ditemukan secara signifikan menjadi faktor risiko maternal untuk kelahiran BBLR
\end{abstract}

Kata Kunci : Bayi Berat Lahir Rendah, Faktor risiko, Systematic review

Abstract

Background: Low Birth Weight Babies (LBW) accounts for 60 - $80 \%$ of all neonatal deaths in the world. Not the only major predictor of mortality and morbidity in neonates, individuals with a history of LBW have a greater risk of experiencing various diseases such as hypertension, heart disease, and diabetes later in life. This systematic review study aims to identify maternal risk factors that contributing to LBW Method: Articles published between 2015 - 2020 in the Science Direct, Scopus and Cochrane library databases are systematically reviewed. Eleven articles that met the inclusion and exclusion criteria were included as samples for further review. Results regarding maternal risk factors for $L B W$ events are synthesized systematically.Results: From the search results, there were 818 articles, after the screening process, the final results were 11 articles. Risk factors that are significantly related to LBW incidence in the article, are grouped in the subtheme, include: maternal age $(<20$ years, and each increase in age), parity (primipara and grandemultipara), low maternal upper arm circumference, hemoglobin levels less than $11 \mathrm{gr} / \mathrm{dl}$, gestational age below 37 weeks, and complications during pregnancy. Conclusion: maternal age, parity, 
arm circumference, hemoglobin level, gestational age, and complications during pregnancy were significaly found to be maternal risk factors for $L B W$.

Keywords: Low Birth Weight Babies, Risk Factors, Systematic review

\section{PENDAHULUAN}

Salah satu dari delapan tujuan Millenium Development Goals (MDGs) adalah, mengurangi angka kematian balita hingga dua per tiga pada periode tahun 1990 hingga 2015. Tingkat kematian global balita berhasil mengalami penurunan dari 90 menjadi 43 kematian per 1000 kelahiran hidup. Meskipun mengalami tingkat penurunan yang mengesankan, hasil tersebut belum mencapai target yang ditentukan (United Nations, 2015). Sebagian besar kematian balita disebabkan oleh kematian neonatal, dimana 6080\% kematian neonatal ini akibat Bayi berat Lahir Rendah (BBLR) (WHO, 2019).

Bayi Berat Lahir Rendah (BBLR) didefinisikan sebagai bayi dengan berat lahir kurang dari 2500 gram. Tingginya kematian pada BBLR disebabkan oleh komplikasi, seperti hipotermia, hipoglikemia, asfiksia, ketidak seimbangan cairan dan elektrolit, hiperbilirubinemia, anemia, malnutrisi, dan sepsis (Astria et al., 2016). BBLR tidak hanya menjadi prediktor utama bagi mortalitas dan morbiditas pada neonatus, BBLR juga meningkatkan risiko penyakit tidak menular di kemudian hari (WHO, 2014).

Kelahiran prematur, gangguan pertumbuhan janin, atau kombinasi dari keduanya dapat menjadi penyebab paling umum kelahiran BBLR Selain itu mungkin dapat disebabkan oleh karena berbagai faktor, seperti faktor janin, faktor ibu, faktor plasenta atau kombinasi dari berbagai faktor tersebut, yang mengakibatkan gangguan pada proses transportasi nutrisi pada plasenta (Singh, Chouhan dan Sidhu, 2009).

Jumlah angka kejadian BBLR yang tinggi dan dampak terhadap kematian bayi yang besar, memerlukan upaya bahwa setiap bayi lahir dalam kondisi sehat. Hal ini dapat dimulai dari mempersiapkan kondisi ibu yang sehat, serta dapat menjalani proses kehamilan dan persalinan dengan aman (UNICEF, 2004). Selain itu perlu melakukan identifikasi faktor risiko yang berpotensi menyebabkan BBLR dan melakukan intervensi yang tepat terhadap faktor risiko tersebut.

Tujuan dalam penelitian ini untuk menganalisis faktor risiko pada ibu yang dapat menyebabkan terjadinya kelahiran bayi dengan berat lahir rendah dengan menggunakan studi systematic review 


\section{METODE}

Penelitian ini menggunakan Studi Systematic Review. Sumber artikel berasal dari tiga elektronik database Science Direct, Scopus, dan Cochrane library. Kata kunci pencarian menggunkan Boolean Operator meliputi OR/AND/NOT. Istilah pencarian literatur yang digunakan adalah Neonate OR Newborn AND "Low Birth Weight" OR "LBW” OR “ Birth Weight” OR “Born Weight” AND “Risk Factor” OR “Maternal Risk Factor".

Kriteria Inklusi dan Eksklusi : Kriteria inklusi (artikel yang diterbitkan tahun 20152020, artikel dalam Bahasa inggris, full text literature and free access), Kriteria eksklusi (Sumber berasal dari Non-Research Study (Conference papers, book chapters, reports), Sumber berupa Systematic review studies, Faktor risiko pada janin yang menyebabkan BBLR).

Seleksi studi dan ekstraksi data: Hasil pencarian literatur dari tiga database, diekspor pada aplikasi EndNote9, artikel yang mirip atau terduplikasi dikeluarkan. Artikel yang tidak sesuai dengan tujuan penelitian, maupun kriteria inklusi dan eksklusi juga dikeluarkan. Hasil pencarian yang telah tersaring diekspor kedalam file tabel excel untuk mempermudah proses pengelompokan data, meliputi : judul artikel, penulis, tahun terbit, tujuan dalam artikel, instrumen penelitian, hasil dan kesimpulan dalam isi jurnal

Penilaian kualitas : Penilaian kualitas artikel, menggunakan alat bantu Quality Assessment Tool for Quantitative Studies dari Effective Public Health Practice Project (EPHPP). Alat bantu EPHPP ini dipilih karena memiliki indikator penilaian yang jelas (selection bias, study design, confounder, blinding, data collection methode, withdrawls and dropouts, serta komponen tambahan antara lain, intervention integrity dan analyses). Hasil dari penilaian kualitas jurnal berupa strong, moderate, dan weak.

Analisis dan sintesis : Hasil-hasil mengenai faktor-faktor risiko yang mengakibatkan BBLR pada tiap artikel pada artikel dikelompokkan dalam subtema yang sama.

\section{HASIL DAN PEMBAHASAN}

Didapatkan hasil total 818 artikel, setelah dilakukan proses screening didapatkan hasil akhir 11 artikel. Artikel yang didapat mewakili berbagai negara antara lain: 8 artikel dilakukan di benua Afrika (Ethiopia, Ghana), dan 3 Artikel di benua Asia (Nepal, Kamboja, dan Malaysia). 
Hasil penilaian kuaitas literatur menggunakan Quality Assessment Tool for Quantitative Studies dari Effective Public Health Practice Project (EPHPP). Di dapatkan 1 artikel dengan nilai strong, 4 artikel dengan nilai moderate, dan 6 artikel dengan nilai weak.

\section{Grafik 1 Bagan Alur Proses Seleksi}

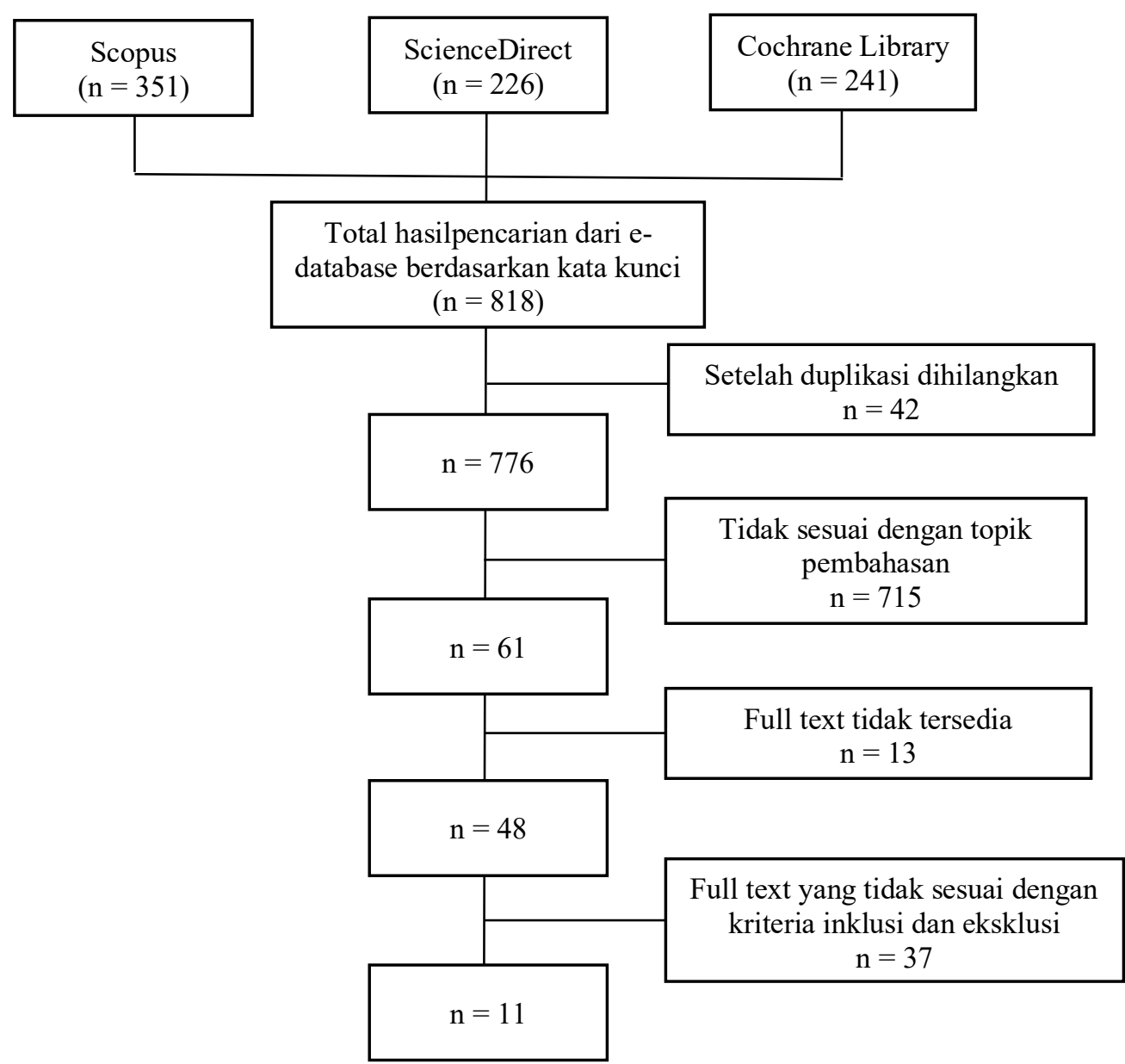

Table 1 Karakteristik Literature

\begin{tabular}{|c|c|c|c|c|c|}
\hline No & Sumber & Setting & Faktor risiko BBLR & $\begin{array}{l}\text { Metode } \\
\text { Studi }\end{array}$ & $\begin{array}{c}\text { Penilaian } \\
\text { Kualitas }\end{array}$ \\
\hline 1 & $\begin{array}{l}\text { (Abera, Ejara } \\
\text { dan } \\
\text { Gebremedhin, } \\
\text { 2019) }\end{array}$ & Ethiopia & $\begin{array}{c}\text { Lingkar lengan ibu }<23 \mathrm{~cm}, \text { Kadar } \\
\text { hemoglobin }<11 \mathrm{gr} / \mathrm{dl}\end{array}$ & $\begin{array}{c}\text { cross- } \\
\text { sectional } \\
\text { study. }\end{array}$ & Weak \\
\hline 2 & $\begin{array}{l}\text { (Aboye et al., } \\
\text { 2018) }\end{array}$ & Ethiopia & Usia kehamilan $<37$ minggu & $\begin{array}{c}\text { cross- } \\
\text { sectional } \\
\text { study. }\end{array}$ & Weak \\
\hline
\end{tabular}




\begin{tabular}{|c|c|c|c|c|c|}
\hline 3 & $\begin{array}{l}\text { (Adam et al., } \\
\text { 2019) }\end{array}$ & Ghana & $\begin{array}{l}\text { Kadar hemoglobin }<11 \mathrm{gr} / \mathrm{dl}, \\
\text { persalinan prematur }\end{array}$ & $\begin{array}{l}\text { Case } \\
\text { Control } \\
\text { study }\end{array}$ & Strong \\
\hline 4 & $\begin{array}{l}\text { (Asmare et al., } \\
\text { 2018) }\end{array}$ & Ethiopia & $\begin{array}{l}\text { Persalinan prematur, lingkar lengan } \\
<23 \mathrm{~cm} \text {, komplikasi selama hamil, }\end{array}$ & $\begin{array}{l}\text { Case } \\
\text { Control } \\
\text { study }\end{array}$ & Moderate \\
\hline 5 & $\begin{array}{l}\text { (Chhea, Ir dan } \\
\text { Sopheab, 2018) }\end{array}$ & Kamboja & Kelahiran pertama, & $\begin{array}{l}\text { Analisis } \\
\text { data } \\
\text { sekunder }\end{array}$ & Weak \\
\hline 6 & $\begin{array}{l}\text { (Hailu dan } \\
\text { Kebede, 2018) }\end{array}$ & Ethiopia & $\begin{array}{l}\text { Usia kehamilan }<37 \text { minggu, } \\
\text { komplikasi selama kehamilan }\end{array}$ & $\begin{array}{l}\text { Case } \\
\text { Control } \\
\text { study }\end{array}$ & Moderate \\
\hline 7 & $\begin{array}{l}\text { (Kaur et al., } \\
\text { 2019) }\end{array}$ & Malaysia & $\begin{array}{l}\text { Lingkar lengan ibu }<23 \mathrm{~cm} \text {, paritas } \\
\text { rendah, ibu berusia tua }\end{array}$ & $\begin{array}{l}\text { cross- } \\
\text { sectional } \\
\text { study }\end{array}$ & Weak \\
\hline 8 & $\begin{array}{l}\text { (Mekie dan } \\
\text { Taklual, 2019) }\end{array}$ & Ethiopia & $\begin{array}{l}\text { Kadar hemoglobin }<11 \mathrm{~g} / \mathrm{dl}, \\
\text { graviditas tinggi }\end{array}$ & $\begin{array}{l}\text { cross- } \\
\text { sectional } \\
\text { study }\end{array}$ & Weak \\
\hline 9 & $\begin{array}{l}\text { (Mohammed et } \\
\text { al., 2019) }\end{array}$ & Ghana & $\begin{array}{l}\text { Usia kehamilan, Paritas, Kadar } \\
\text { hemoglobin rendah }\end{array}$ & $\begin{array}{l}\text { cross- } \\
\text { sectional } \\
\text { study } \\
\end{array}$ & Weak \\
\hline 10 & $\begin{array}{l}\text { (Sharma et al., } \\
\text { 2015) }\end{array}$ & Nepal & $\begin{array}{l}\text { Kadar hemoglobin, usia ibu lebih } \\
\text { muda }\end{array}$ & $\begin{array}{l}\text { Case } \\
\text { Control } \\
\text { study }\end{array}$ & Moderate \\
\hline 11 & $\begin{array}{l}\text { (Siyoum dan } \\
\text { Melese, 2019) }\end{array}$ & Ethiopia & $\begin{array}{l}\text { Lingkar lengan ibu kurang dari } 22 \\
\mathrm{~cm}, \text { mengalami komplikasi pada } \\
\text { kehamilan, }\end{array}$ & $\begin{array}{l}\text { Case } \\
\text { Control } \\
\text { study }\end{array}$ & Moderate \\
\hline
\end{tabular}

Berdasarkan karakteristik literature yang telah disajikan pada tabel 1, didapatkan faktor risiko maternal yang berkontribusi terhadap kejadian BBLR antara lain:

1) Usia ibu

Usia ibu lebih muda ( $<20$ tahun) dan setiap peningkatan pada usia ibu dikaitkan dengan risiko bayi lahir dengan BBLR yang lebih tinggi di Nepal dan Malaysia (Sharma et al., 2015; Kaur et al., 2019).

Usia ibu menjadi salah satu faktor risiko yang secara signifikan berkitan dengan kejadian BBLR, hal ini dikaitkan dengan pengaruhnya terhadap kesuburan. Pernyataan ini didukung oleh Agorinya et al., (2018) dan Roy Prasojo (2018) ibu dengan usia $<20$ tahun dan $>34$ tahun memiliki risiko yang lebih besar untuk melahirkan bayi BBLR dari pada ibu dengan usia 20-34 tahun. Fertilitas berkurang pada usia 20 tahun dan menurun sangat cepat ketika berusia 35 tahun. Ibu berusia muda memiliki kondisi kondisi endometrium yang belum berkembang sempurna, sedangkan pada usia lebih dari 35 tahun kondisi endometrium menjadi kurang subur (Rahfiludin dan Dharmawan, 2018). Ibu dengan usia muda masih dalam tahap pertumbuhan biologis dan belum cukup matang 
secara fisik maupun emosional, disisi lain ibu dengan usia yang lebih tua berisiko mengalami anomali kromosom, komplikasi pada kehamilan seperti preeklamsia, diabetes yang berdampak pada kejadian BBLR (Badalyan, 2014).

2) Paritas

Hasil penelitian di Kamboja dan Malaysia menemukan hubungan yang signifikan pada status paritas yang rendah dengan BBLR (Chhea, Ir dan Sopheab, 2018 ; Kaur et al., 2019), sementara status paritas yang lebih tinggi juga berhubungan dengan kejadian BBLR di Ethiopia dan Ghana (Mekie dan Taklual, 2019; Mohammed et al., 2019).

Kehamilan dan persalinan pertama memungkinkan risiko karena ibu belum pernah mengalami kehamilan sebelumnya. Pada setiap kehamilan berikutnya memungkinkan tubuh ibu mengalami peingkatan aliran darah utero plasenta yang lebih efisien pada kehamilan selanjutnya (Kaur et al., 2019). Hasil ini sejalan dengan Mahu (2016) dan Sulistyawati (2015). Kemampuan rahim untuk memenuhi nutrisi pada kehamilan selanjutnya semakin menurun seiring dengan meningkatnya status paritas, sehingga proses transprtasi nutrisi ibu kepada janin terganggu dan berdampak pada lahirnya BBLR (Sulistyawati, 2015).

3) Lingkar lengan atas yang rendah

Kelahiran BBLR ditemukan pada ibu dengan ukuran lingkar lengan atas yang rendah di negara Ethiopia dan Malaysia (Asmare et al., 2018; Abera, Ejara dan Gebremedhin, 2019; Kaur et al., 2019; Siyoum dan Melese, 2019).

Lingkar lengan ibu menjadi indikator cadangan protein dan energi dalam tubuh serta menjadi sebagai salah satu penentu status gizi ibu sebelum hamil. Ukuran LILA yang rendah menunjukan adanya kondisi tidak terpenuhinya kebutuhan energi, kekurangan energi yang kronis menyebabkan ibu hamil tidak memiliki cadangan zat gizi yang adekuat untuk memenuhi kebutuhan fisiologis selama masa kehamilanya seperti, peningkatan hormon dan peningkatan volume darah untuk pertumbuhan janin (Sulistyawati, 2015).

4) Kadar hemoglobin kurang dari $11 \mathrm{gr} / \mathrm{dL}$

Kadar hemoglobin yang rendah, kurang dari $11 \mathrm{gr} / \mathrm{dl}$ secara signifikan berhubungan dengan kejadian BBLR di Ethiopia, Ghana, dan Nepal (Abera, Ejara dan Gebremedhin, 2019; Adam et al., 2019; Sharma et al., 2015; Aboye et al., 2018; Mekie dan Taklual, 2019; Mohammed et al., 2019). 
Anemia dalam kehamilan adalah kondisi ibu dengan kadar hemoglobin dibawah 11 gr/dl pada trimester 1 dan 3, atau kadar hemoglobin kurang dari 10,5 gr/dl pada trimester 2 (Rahfiludin dan Dharmawan, 2018). Anemia yang terjadi pada masa kehamilan dapat menyebabkan hipoksia janin. Hal ini berdampak pada berkurangnya aliran oksigen dan nutrisi dari ibu ke janin, yang dapat mengganggu pertumbuhan dan perkembangan janin di dalam rahim dan menyebabkan bayi terlahir dengan berat lahir kurang dari 2500 gram (Aboye et al., 2018; Abera, Ejara dan Gebremedhin, 2019).

5) Usia kehamilan kurang dari 37 minggu

Persalinan prematur, yang terjadi pada usia kehamilan $<37$ minggu di Ghana dan Ethiopia, menjadi salah satu prediktor terjadinya kelahiran BBLR (Aboye et al., 2018; Adam et al., 2019; Asmare et al., 2018; Hailu dan Kebede, 2018; Mohammed et al., 2019).

Usia kehamilan memainkan peran penting dalam menentukan berat lahir. WHO memperkirakan sekitar satu per tiga dari seluruh BBLR di dunia disebabkan oleh prematuritas (Aboye et al., 2018). Hal ini jelas bahwa bayi yang lahir sebelum berusia aterm, baik disebabkan oleh karena faktor ginekologis maupun medis, berisiko lebih tinggi lahir dalam kondisi BBLR, karena pertumbuhan pada usia $<37$ minggu janin belum mencapai waktu pertumbuhan dan perkembangan yang optimal (Aboye et al., 2018; Hailu dan Kebede, 2018).

6) Komplikasi selama kehamilan

Tiga Penelitian di Ethiopia mendapatkan hasil BBLR memiliki hubungan dengan kondisi komplikasi yang di alami oleh ibu selama masa kehamilan (Asmare et al., 2018; Hailu dan Kebede, 2018; Siyoum dan Melese, 2019).

Terjadinya tanda-tanda komplikasi selama kehamilan (seperti perdarahan, sakit kepala, penglihatan mata kabur, demam dan sakit perut hebat) merupakan salah satu faktor risiko berat lahir rendah. Hal ini dikarenakan tanda dan gejala komplikasi selama kehamilan merupakan indikasi dari adanya gangguan selama kehamilan yang berdampak negatif tidak hanya pada ibu namun juga pada janin. Ibu dengan preeklamsia atau hipertensi saat hamil dapat mengalami abruption plasenta yang mengakibatkan berkurangnya perfusi plasenta pada janin dan menyebabkan bayi terlahir dengan BBLR atau kematian janin (Asmare et al., 2018; Hailu dan Kebede, 2018). Ibu hamil dengan hiperemesis gravidarum mengalami mual dan muntah yang terus menerus, dapat 
mengakibatkan dehidrasi dan kekurangan zat gizi (Sulistyawati, 2015). Selain itu komplikasi perdarahan pada kehamilan seperti plasenta previa, solusio plasenta, ruptur uteri dapat meningkatkan risiko kematian ibu dan janin, kelahiran prematur, dan kematian perinatal. Kelahiran prematur dan gawat janin sering tidak dapat terhindarkan oleh karena tindakan terminasi kehamilan yang terpaksa dilakukan pada usia kehamilan $<37$ minggu. Bayi yang terlahir prematur belum mencapai tahap pertumbuhan dan perkembangan yang optimal, sehingga berisiko lebih besar terlahir dengan berat $<2500$ gram (prawirohardjo, 2016).

\section{KESIMPULAN DAN SARAN}

Pada studi systematic review ini terdapat faktor-faktor risiko maternal yang berperan secara signifikan pada terjadinya kelahiran bayi dengan BBLR antara lain, usia ibu, paritas, lingkar lengan atas yang rendah, kadar hemoglobin kurang dari $11 \mathrm{gr} / \mathrm{dL}$, usia kehamilan <37 minggu, dan komplikasi selama kehamilan. Oleh karena itu diharapkan petugas kesehatan dapat meningkatkan pelayanan kesehatan untuk mencegah terjadinya kelahiran BBLR dengan cara mendeteksi faktor risiko, dan melakukan intervensi yang tepat pada setiap faktor risiko. Penelitian selanjutnya diharapkan dapat memperluas sumber $e$-database, memperlebar rentan tahun dan lebih banyak memuat banyak jurnal, serta mengidentifikasi lebih lanjut faktor risiko lain pada kejadian BBLR.

\section{DAFTAR PUSTAKA}

Abera, Z., Ejara, D. dan Gebremedhin, S. (2019). Nutritional and non-nutritional factors associated with low birth weight in Sawula Town, Gamo Gofa Zone, Southern Ethiopia. BMC Research Notes, 12(1). doi: 10.1186/s13104-019-4529-0.

Aboye W. et al. (2018). Prevalence and associated factors of low birth weight in Axum town, Tigray, North Ethiopia. BMC Res Notes. 2018 Oct 1;11(1):684. doi: 10.1186/s13104-018-3801-z. PMID: 30285895; PMCID: PMC6167810.

Adam, Z. et al. (2019). Determinants of low birth weight in neonates born in three hospitals in Brong Ahafo region, Ghana, 2016- an unmatched case-control study. BMC Pregnancy and Childbirth, 19(1). doi: 10.1186/s12884-019-2315-6.

Agorinya, I. A. et al. (2018). Socio-demographic determinants of low birth weight: Evidence from the Kassena-Nankana districts of the Upper East Region of Ghana. PloS ONE, 13(11), pp. 1-10. Doi: 10.1371/journal.pone.0206207.

Asmare, G. et al. (2018). Determinants of low birth weight among neonates born in Amhara Regional State Referral Hospitals of Ethiopia: Unmatched case control study. BMC Research Notes, 11(1). doi: 10.1186/s13104-018-3568-2.

Astria, Y. et al. (2016). Paediatrica Indonesiana. 56(3), hal. 155-161 
Badalyan, V. (2014). Case Control Study Aimed at Revealing Risk Factors of Low Birth Weight in Yerevan City. Doctoral dissertation. American University of Armenia (AUA)

Chhea, C., Ir, P. dan Sopheab, H. (2018). Low birth weight of institutional births in Cambodia: Analysis of the demographic and health surveys 2010-2014. PLoS ONE, 13(11). doi: 10.1371/journal.pone.0207021.

Hailu, L. D. dan Kebede, D. L. (2018). Determinants of low birth weight among deliveries at a Referral Hospital in Northern Ethiopia. BioMed Research International. doi: $10.1155 / 2018 / 8169615$.

Kandel, K. P. dan Kafle, S. (2017). Risk Factors Associated with Low Birth Weight among Deliveries at Bharatpur Hospital. Journal of Nepal Health Research Council, 15(2), hal. 169-173. doi: 10.3126/jnhrc.v15i2.18208.

Kaur, S. et al. (2019). Risk factors for low birth weight among rural and urban Malaysian women. BMC Public Health, 19. doi: 10.1186/s12889-019-6864-4.

Mahu, S.D. (2016). Hubungan Antara Usia dan Jumlah Paritas Pada Ibu Bersalin Dengan Kejadian BBLR di RSUD Ben Mboi Ruteng. Skripsi. Universitas Airlangga Surabaya.

Mekie, M. dan Taklual, W. (2019). Magnitude of low birth weight and maternal risk factors among women who delivered in Debre Tabor Hospital, Amhara Region, Ethiopia: A facility based cross-sectional study. Italian Journal of Pediatrics, 45(1). doi: 10.1186/s13052-019-0683-1.

Mohammed, S. et al. (2019). Maternal obstetric and socio-demographic determinants of low birth weight: A retrospective cross-sectional study in Ghana. Reproductive health, 16(1). doi: 10.1186/s12978-019-0742-5.

Prawirohardjo, S. (2016). Ilmu Kebidanan. Jakarta: PT Bina Pustaka Sarwono Prawirohardjo.

Rahfiludin, M. Z. dan Dharmawan, Y. (2018). Risk factors associated with low birth weight. Kesmas, 13(2), hal. 75-80. doi: 10.21109/kesmas.v13i2.1719.

Sharma, S. R. et al. (2015). Low birth weight at term and its determinants in a tertiary hospital of nepal:A case-control study. PLoS ONE, 10(4). doi: 10.1371/journal.pone.0123962.

Singh, G., Chouhan, R. dan Sidhu, K. (2009). Maternal factors for low birth weight babies. Medical Journal Armed Forces India. Director General, Armed Forces Medical Services, 65(1), hal. 10-12. doi: 10.1016/S0377-1237(09)80045-2.

Siyoum, M. dan Melese, T. (2019). Factors associated with low birth weight among babies born at Hawassa University Comprehensive Specialized Hospital, Hawassa, Ethiopia. Italian Journal of Pediatrics, 45(1). doi: 10.1186/s13052-019-0637-7.

Sulistyawati, W. (2015). Pengaruh Faktor Maternal Terhadap Kejadian Berat Badan Lahir Rendah Di Kabupaten Mojokerto. Tesis. Universitas Airlangga Surabaya

United Nations (2015). The Millennium Development Goals Report. United Nations, hal. 72. doi: 978-92-1-101320-7

United Nations Children's Fund. (2004). Low Birthweight Country, Regional and Global Estimates. UNICEF, New York.

World Health Organization. (2014). WHA Global Nutrition Targets 2025: Low Birth Weight Policy Brief. [online] WHO. https://www.who.int/nutrition/publications/globaltargets2025policybrief_lbw/en/ (10 Oktober 2019). 